\title{
Evaluation of soils with average potassium content summation for implantation of Musa sp in the municipality of Teotônio Vilela,
} Alagoas

\section{Avaliação de solos com teores médios de potássio para implantação de Musa sp no município de Teotônio Vilela, Alagoas}

Cosme Ângelo da Silva ${ }^{1 *}$, Alciênia Silva Albuquerque ${ }^{2}$, Amanda de Lira Freitas ${ }^{3}$, Denise Maria Santos ${ }^{4}$, Alexsandro Gonçalves Pacheco ${ }^{1}$, Camila Alexandre Cavalcante de Almeida ${ }^{1}$, Andréa de Vasconcelos Freitas Pinto ${ }^{1}$, Maria José de Holanda Leite ${ }^{1}$

\begin{abstract}
Soil fertility is one of the crucial factors for agriculture, whose main objective is to increase production. Therefore it is extremely important to know the nutritional requirement of cultivars. Fertility-focused studies are essential for fertilization recommendations in all regions, especially in banana cultivation which is a very demanding plant in fertility. Thus, the present work aimed to evaluate soil fertility, emphasizing the quantification of nutrients necessary to ensure the agricultural productivity of musa sp. The research was developed at laudelino farm, municipality of Teotônio Vilela/Alagoas, between 2019 and 2020, where soil amotragens were performed, randomly collected in the $0-20 \mathrm{~cm}$ depth layer, removing $1 \mathrm{~kg}$ of soil and sent to the soil laboratory of the Campus of Engineering and Agrarian Sciences (CECA) of the Federal University of Alagoas (UFAL) located in the municipality of Rio Largo-AL, for chemical analysis. The hydrogenic potential $(\mathrm{pH})$, phosphorus $(\mathrm{P})$ and potassium $(\mathrm{K}+)$ accessible were analyzed; calcium $(\mathrm{Ca}+2)$ and tradable magnesium $(\mathrm{Mg}+2)$; saturation by exchangeable aluminum $(\mathrm{m} \%)$, cation exchange capacity $\mathrm{CTC}$ at $\mathrm{pH} 7.0(\mathrm{~T})$; base saturation (V\%) and; organic matter (OM). As a result of the analysis, the following results were obtained: $\mathrm{pH}$ content (5.6); OM $(14.1 \mathrm{~g} / \mathrm{kg}) \mathrm{P}\left(5.0 \mathrm{mg} / \mathrm{dm}^{3}\right) \mathrm{K}\left(110 \mathrm{mg} / \mathrm{dm}^{3}\right), \mathrm{Ca} 2+(3.42$ cmolc $\left./ \mathrm{dm}^{3}\right), \mathrm{Mg} 2+\left(2.53 \mathrm{cmolc} / \mathrm{dm}^{3}\right) ; \mathrm{Al} 3+\left(0.00 \mathrm{cmolc} / \mathrm{dm}^{3}\right), \mathrm{H}\left(4.41 \mathrm{cmolc} / \mathrm{dm}^{3}\right)$, and CTC (T) $(10.73$ cmolc/dm $\left./ \mathrm{m}^{3}\right) ; \mathrm{m}(0.0 \%)$ and $\mathrm{V}(59 \%)$. Based on the above results, it is suggested the application of 1,103 $\mathrm{kg}$ of limestone in order to increase the base saturation to $70 \%$, in addition to the addition of $50 \mathrm{~kg} / \mathrm{ha}$ of N and $343.5 \mathrm{~kg} / \mathrm{ha}$ of P2O5 and $96.7 \mathrm{~kg} / \mathrm{ha}$ of K2O. It is worth mentioning that their applications in the soil must be carried out through sources of $837.8 \mathrm{~kg} / \mathrm{ha}$ of triple superphosphate; $161.2 \mathrm{~kg} / \mathrm{ha}$ of potassium chloride and $111 \mathrm{~kg} / \mathrm{ha}$ of urea. It is also essential to add 30 to $50 \mathrm{t} / \mathrm{ha}$ of organic matter, such as bovine manure to the soil, aiming at better utilization of the material by crops.
\end{abstract}

Palavras-chave: Fertilization; Soil management; Mineral nutrition;

\section{RESUMO}

A fertilidade do solo é um dos fatores cruciais para a agricultura, o qual tem como principal objetivo aumentar a produção. Por isso é extremamente importante conhecer a exigência nutricional das cultivares. Estudos voltados para fertilidade são essenciais para recomendações de adubação em todas as regiões, especialmente no cultivo da bananeira que é uma planta bastante exigente em fertilidade. Assim, o presente

\footnotetext{
${ }^{1}$ Universidade Federal de Alagoas - UFAL, Campus de Engenharias e Ciências Agrárias CECA/UFAL

* E-mail: maryholanda@gmail.com

${ }^{2}$ Universidade Federal de Campina Grande - UFCG/Centro de Saúde e Tecnologia Rural - CSTR.

${ }^{3}$ Universidade Federal Rural de Pernambuco - UFRPE.

${ }^{4}$ Instituto Dom José de Educação e Cultura - IDJ/UVA.
} 
trabalho buscou avaliar a fertilidade do solo, dando ênfase à quantificação dos nutrientes necessários para garantir a produtividade agrícola da cultura Musa sp. A pesquisa foi desenvolvida na fazenda Laudelino, município de Teotônio Vilela/Alagoas, entre os anos de 2019 a 2020 onde foram realizadas amotragens de solo, coletadas de forma aleatória na camada de $0-20 \mathrm{~cm}$ de profundidade, retirando-se $1 \mathrm{~kg}$ de solo e encaminhadas para laboratório de solo do Campus de Engenharias e Ciências Agrárias (CECA) da Universidade Federal de Alagoas (UFAL) localizada no município de Rio Largo- AL, para análises químicas. Analisou-se o potencial hidrogeniônico $(\mathrm{pH})$, fósforo $(\mathrm{P})$ e potássio $(\mathrm{K}+)$ acessível; cálcio $(\mathrm{Ca}+2)$ e magnésio $(\mathrm{Mg}+2)$ trocável; saturação por alumínio trocável $(\mathrm{m} \%)$, capacidade de troca cátions $\mathrm{CTC}$ a pH 7,0 (T); saturação por bases (V\%) e; matéria orgânica (MO). Conforme resultado da análise, foram obtidos os seguintes resultados: teores de $\mathrm{pH}(5,6) ; \mathrm{MO}(14,1 \mathrm{~g} / \mathrm{kg}) \mathrm{P}\left(5,0 \mathrm{mg} / \mathrm{dm}^{3}\right) \mathrm{K}\left(110 \mathrm{mg} / \mathrm{dm}^{3}\right), \mathrm{Ca} 2+(3,42$ cmolc/dm $\left.{ }^{3}\right), \mathrm{Mg} 2+\left(2,53 \mathrm{cmolc} / \mathrm{dm}^{3}\right) ; \mathrm{Al} 3+\left(0,00 \mathrm{cmolc} / \mathrm{dm}^{3}\right), \mathrm{H}\left(4,41 \mathrm{cmolc} / \mathrm{dm}^{3}\right)$, e CTC (T) $(10,73$ cmolc/dm $\left.{ }^{3}\right) ; \mathrm{m}(0,0 \%)$ e V $(59 \%)$. A partir dos resultados supracitados, sugere-se a aplicação de $1.103 \mathrm{~kg}$ de calcário calcítico com a finalidade de elevar a saturação por base para $70 \%$, além da adição de $50 \mathrm{~kg} / \mathrm{ha}$ de $\mathrm{N}$ e de $343,5 \mathrm{~kg} / \mathrm{ha}$ de $\mathrm{P} 2 \mathrm{O} 5$ e $96,7 \mathrm{~kg} / \mathrm{ha}$ de $\mathrm{K} 2 \mathrm{O}$. Vale destacar que, suas aplicações no solo, devem ser realizadas através de fontes de $837,8 \mathrm{~kg} / \mathrm{ha}$ de superfosfato triplo; $161,2 \mathrm{~kg} / \mathrm{ha}$ de cloreto de potássio e $111 \mathrm{~kg} / \mathrm{ha}$ de ureia. Também é essencial a adição de 30 a 50 t/ha de matéria orgânica como, por exemplo, esterco bovino ao solo, visando melhor aproveitamento do material pelas culturas.

Keywords: Adubação; Manejo do solo; Nutrição mineral;

\section{INTRODUÇÃO}

Banana (Musa sp.) is one of the most consumed fruits in the world, produced on a large scale in tropical countries. Brazil is one of the world's largest producers of fruit, occupying fourth place, totaling 6.7 million tons (IBGE, 2020). Among the Brazilian states, São Paulo, Bahia, Minas Gerais and Santa Catarina stand out for their national production. Banana farming is characterized as an activity of great economic importance worldwide. In Brazil, its wide production is due to the fact that its adaptability in most regions, in addition to the rapid return of invested capital, since, depending on the cultivar, it comes to return already in the first year of planting (DINIZ et al., 2014).

In the state of Alagoas, banana cultivation is a profitable activity for small and medium-sized producers, however most plantations are located in forest regions and near the coast. Aiming at high productivity and good development of banana crop, it is necessary to meet all its nutritional requirements. Although a small part of the nutrients are supplied by the soil and the rest of crops that are from previous harvests, so that their productive potential is expressed, it is necessary to apply corrective such as limestone and chemical fertilizers, as well as organic matter for greater utilization of nutrients (LOPEZ, 1994).

In addition, the amount of fertilizer to be applied to the crop depends on its productive genetic potential, plant population density, phytosanitary status and, mainly, the relationship of nutrients in the soil and the root system, which is of great importance 
in the absorption of minerals. It is known that nitrogen $(\mathrm{N})$ and potassium $(\mathrm{K})$ are the most necessary and important elements for plant growth and development, since they are the most absorbed macronutrients and act, among other functions, in increasing the number of pencas and promotes production bunches and pencas, respectively; while phosphorus (P) acts on the functions of floral organs, being the most exported element by fruits (BORGES et al., 2015).

It is worth mentioning that the imbalance between nitrogen and potassium triggers postharvest problems, as it leads to abscission of fruits that are already ripe in the bunch. The low amount of potassium leads to nitrogen accumulation in the ammoniacal form, which, when in excess, leads to a great difficulty in fruiting the bunch, producing bunches with spaced pens and with little resistance in transport (GUERRA et al., 1986).

Thus, the present work was developed with the objective of verifying the concentrations of the elements contained in the soil in the municipality of Teotônio Vilela/Alagoas, in laudelino farm, for the implantation of Musa sp. for higher agricultural productivity. In addition, research aims to show farmers that soils with average fertility will not need large fertilization sums to have better production, thus having less expense in the implementation of the crop.

\section{MATERIAL AND METHODS}

\section{Characterization of the study área}

The present work was conducted at laudelino farm, located in the municipality of Teotônio Vilela (Figure 1), where the Mesoregion of eastern Alagoas is located, with latitude $09^{\circ} 54^{\prime} 22^{\prime \prime}$ and longitude $36^{\circ} 21^{\prime} 08^{\prime \prime}$ West, 156 meters above sea level and 101 $\mathrm{km}$ from the capital. The climate is classified with an average temperature of $24^{\circ} \mathrm{C}$ and precipitation on an annual average is $1134 \mathrm{~mm}$ /year (CASTRO MASCARENHAS et al., 2005). It has wavy or slightly wavy relief being fragile and susceptible to erosion due to its slope of (5 to $10 \%$ slope) (VERDUM et al., 2016).

The soils of the region have several characteristics in their pedological nature, such as latosols and podzolics in high and high residues; With Podzol Fragipã, Podzol Plinticos and Podzois at low depressions in the plane, by the podzólocos concrecion in dry, dead and slope areas and gleissolos and alluvial soils in the lower areas (MASCARENHAS et al., 2005). 
Figure 1. Area of 1 hectare of laudelino farm in Teotônio Vilela- AL

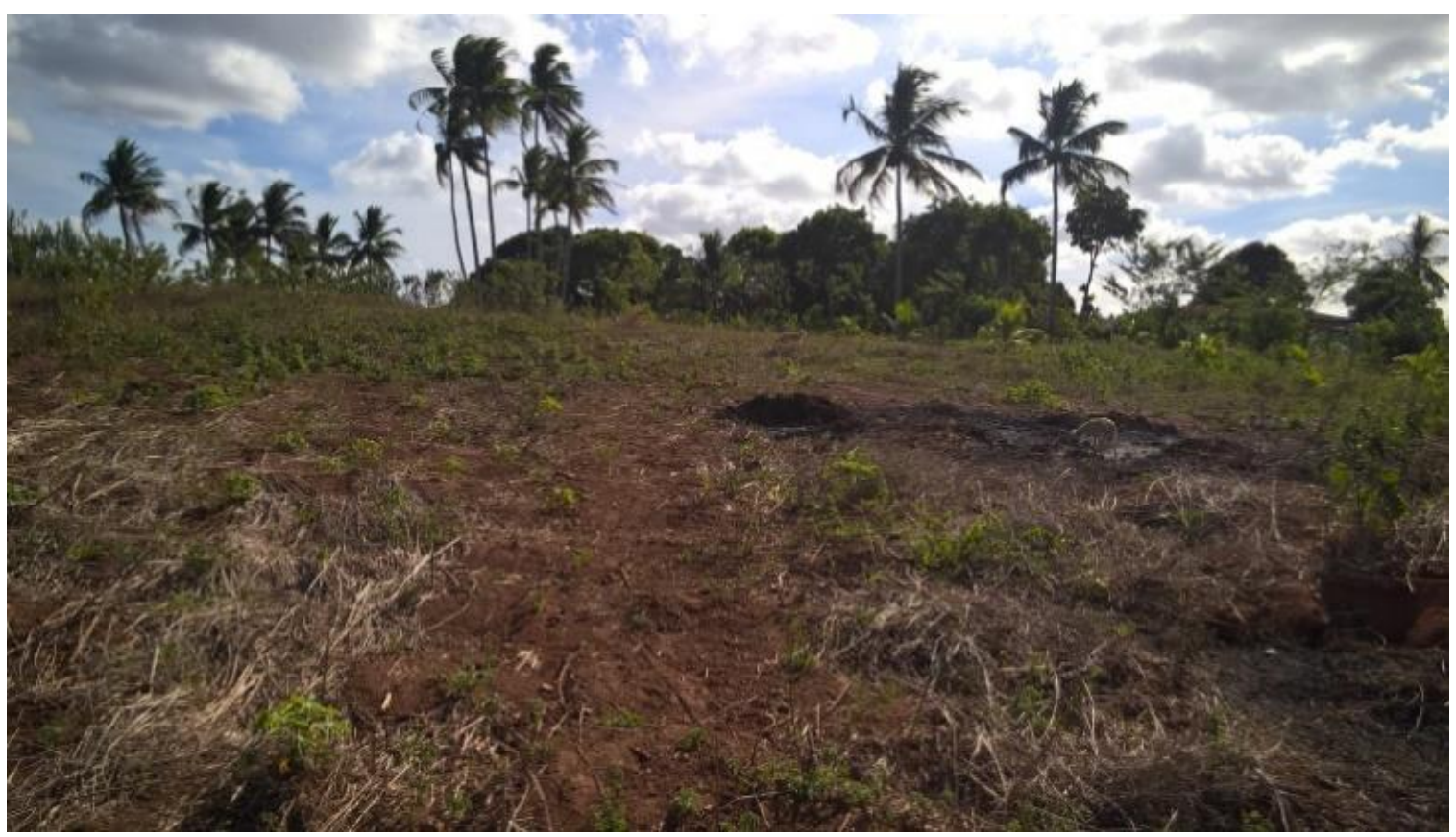

Source: (Silva, 2019).

The research was carried out between 2019 and 2020, where soil collections were randomly performed in 1 hectare (ha) in the $0-20 \mathrm{~cm}$ depth layer, totaling 15 samples, each with approximately $0.5 \mathrm{dm}^{3}$ of soil, from simple collection were mixed to make up a single composite sample and from this $1 \mathrm{~kg}$ of soil was removed for subsequent fertilization analyses. The analyses were carried out in the soil laboratory of the Campus of Engineering and Agrarian Sciences (CECA) of the Federal University of Alagoas (UFAL), located in the municipality of Rio Largo, AL.

The parameters established for quantification were the hydrogenionic potential $(\mathrm{pH})$, phosphorus $(\mathrm{P})$ and potassium $(\mathrm{K}+)$ accessible; calcium $(\mathrm{Ca}+2)$ and tradable magnesium $(\mathrm{Mg}+2)$; saturation by exchangeable aluminum (m\%), CTC at $\mathrm{pH} 7.0(\mathrm{~T})$; base sum (V\%) and; organic matter (OM). These are determining indices in soil fertility.

The recommendations, interpretations and calculations of fertilization for the soil, later for the implantation of banana cultivation, were carried out based on the Manual of Recommendation of Cathem and Fertilization for the State of Espírito Santo (PREZOTTI et al., 2007).

In view, the values of the elements presented in the soil by soil chemical analysis were classified as low, medium and high. The amount of $\mathrm{pH}, \mathrm{P}, \mathrm{k}+\mathrm{Ca}+2, \mathrm{Mg}+2, \mathrm{~V} \%$, $\mathrm{m} \%, \mathrm{SB}, \mathrm{Al}+3, \mathrm{CTC}$ and $\mathrm{OM}$. 


\section{Soil nutrient levels for the purpose of interpreting soil chemical analysis results.}

The results of nutrient contents were determined by chemical analysis of the soil and compared with the reference values, arranged in table 1 of interpretation, which allows a better understanding for the classification of the soil fertility level and subsequent indication of the amount of correctives and fertilizers to be applied for better growth and development of the crop, maximizing its efficiency.

Table 1. Interpretation class for the elements $\mathrm{pH}, \mathrm{P}, \mathrm{K}, \mathrm{m} \%, \mathrm{~V} \%, \mathrm{OM}, \mathrm{Ca}, \mathrm{Mg}-$ Average reference standards for evaluation of soil analysis results, adapted from Prezotti et al., 2017.

\begin{tabular}{|c|c|c|c|c|}
\hline \multirow[t]{2}{*}{ Elements/Unit } & \multirow[t]{2}{*}{ Method } & \multicolumn{3}{|c|}{ Standards or Nutritional Levels } \\
\hline & & Low & Medium & High \\
\hline $\mathrm{pH}$ & Water & $<5,0$ & $5,0-5,9$ & $>6,0$ \\
\hline $\mathrm{P} \mathrm{mg} / \mathrm{dm}^{3}$ & Mehlich-1 & $<5,0$ & $5,0-10$ & $>10$ \\
\hline $\begin{array}{l}\mathrm{K} \mathrm{mg} / \mathrm{dm}^{3} \\
\mathrm{cmolc} / \mathrm{dm}^{3}\end{array}$ & Mehlich-1 & $<60$ & $60-150$ & $>150$ \\
\hline $\mathrm{Ca} \mathrm{cmolc/ \textrm {dm } ^ { 3 }}$ & $\mathrm{KCl} 1 \mathrm{~mol} / \mathrm{L}$ & $<1,5$ & $1,5-4,0$ & $>4,0$ \\
\hline $\mathrm{Mg}$ cmolc/dm ${ }^{3}$ & $\mathrm{KCl} 1 \mathrm{~mol} / \mathrm{L}$ & $<0,5$ & $<0,5$ & $>1,0$ \\
\hline $\mathrm{m} \%$ & $\mathrm{Al} / \mathrm{t} \times 100$ & $<50$ & $50-70$ & $>70$ \\
\hline $\mathrm{V} \%$ & & $<50$ & $50-70$ & $>70$ \\
\hline $\begin{array}{l}\text { CTC }(\mathrm{T}) \\
\text { cmolc/dm3 }\end{array}$ & $\mathrm{SB}+\mathrm{H}+\mathrm{Al}$ & $<4,5$ & $4,5-10$ & $>10$ \\
\hline MO dag/kg & Calorimeter & $<1,5$ & $1,5-3,0$ & $>3$ \\
\hline
\end{tabular}

Legend: $\mathrm{pH}$ (active acidity) $=$ hydrogen potential, $\mathrm{P}=$ phosphorous, $\mathrm{K}+=$ potassium, $\mathrm{Ca}=$ Calcium, $\mathrm{Mg}=$ magnesium, $\mathrm{Na}+=$ Sodium, $\mathrm{Al} 3+$ (Aluminum): indicates exchangeable acidity, $\mathrm{H}+\mathrm{Al}$ (potential or total acidity): is exchangeable and non-exchangeable acidity, $\mathrm{V} \%$ (base saturation) is the proportion of cation exchange, total CTC or $\mathrm{T}=$ cation exchange capacity, $\mathrm{m} \%=\mathrm{Al} 3+$ saturation, $\mathrm{MO}=$ organic matter.

Source: Mean reference patterns for evaluation of soil analysis results; adapted from Prezotti et al., 2017.

\section{RESULTS AND DISCUSSION}

\section{Soil chemical analysis}

It is observed that, at a depth of $0-20 \mathrm{~cm}$, the soil presented an average acidity of 5.6 (Table 2). It is known that mean $\mathrm{pH}$ values between 5.5 and 6.5 are considered ideal 
for most cultures, because they present intermediate availability of micronutrients and absence of $\mathrm{Al}+3$ (toxic). Thus, the greater availability of the elements in the soil, the plants have greater absorption of fertilizer and utilization of nutrients, maintaining an adequate level for good growth and development (SANTOS et al., 2008).

In the absence of high soil acidity, the minerals disposed of in it can be exploited in larger quantities. The negative load of the soil is a fundamental factor, and may be permanent or temporary, besides that, depending on the $\mathrm{pH}$ value and existing clays, it promotes the growth of plants and roots by finding nutrients and water in the soil in a way available to plants (RAIJ, 1981).

Based on soil sampling of the surface layer 0-20 $\mathrm{cm}$ deep, the P level $\left(5 \mathrm{mg} / \mathrm{dm}^{3}\right)$ was median (Table 2), under these conditions, only some perennial crops, such as banana, since the formation of shoots at the base of the plant allows its constant renewal and can maintain its productivity on average. Probably, in this soil the plants will have an average yield. The adequate amount in the soil, sufficient to reach $40 \%$ to $45 \%$ of production, thus, in the omission or non-application of $\mathrm{P}$ in the crop will not bring good results (MALAVOLTA, 1981).

The amount of phosphate fertilizer to be applied depends on soil and plant factors. Thus, the range of best development of the perennial plant is at $20 \mathrm{mg} / \mathrm{dm} 3$ with this amount of phosphorus, the absorption and efficiency increase with the different form of application: line, track and pitch, the latter being more efficient in the exploration of soil volume by the root system (SILVA et al., 2010)

Potassium (K) resulted in $110 \mathrm{mg} / \mathrm{dm}^{3}$, being classified as medium (Table 2). This soil shows that it has an average amount of potassium, possibly due to the rock of origin being rich in this chemical element, where it suffered level of intent, thus releasing the amount of potassium to the soil, being made available over time. The amount of potassium to be absorbed by the plant depends on its soil content and the concentration of basic cations, such as $\mathrm{Ca}$ and $\mathrm{Mg}$ bonded at the exchange site (MENDES, 2007)

Thus, it recommends to apply the amount of potassium $\left(>150 \mathrm{mg} / \mathrm{dm}^{3}\right)$ according to the need of the crop, in view of the maximum use by the plant and proper export of the elements by the root system (RAIJ, 1991). However, high potassium levels allow a better development of some crops such as bananas, which is quite demanding by the element (PREZOTTI et al., 2007). 
The amounts of exchangeable calcium $(\mathrm{Ca} 2+)$ were classified as average, obtaining a value of $3.42 \mathrm{cmolc} / \mathrm{dm}^{3}$. Magnesium $(\mathrm{Mg} 2+)$ levels were high (2.53 cmolc/ $\mathrm{dm}^{3}$ ). Thus, the use of fertilizers to correct soil acidity is of fundamental importance for agricultural production because it provides the necessary minerals. Soils with exchangeable $\mathrm{Ca} / \mathrm{Mg}$ contents equal to or below 2.0 to $0.5 \mathrm{cmolc} / \mathrm{dm}^{3}$ are considered deficient. Thus, the $\mathrm{Ca} / \mathrm{Mg}$ ratio has to be equal to 3:1, always being maintained for better crop efficiency (SOIL FERTILITY COMMISSION AND CHEMICALS-RS / SC, 2004).

The saturation of $\mathrm{Al} 3+$ aluminum was very low (0\%) (Table 2). The soil is free of toxicity by exchangeable aluminum, which hinders the development of the root system and plant. Thus, the reduction of plant root growth causes toxic aluminum, this phenomenon prevents the absorption of water and nutrients, as this leaves the roots more superficial and fragile, making it difficult to explore by water and nutrients in the lower layers of the soil. The toxicity by aluminum in the soil solution appears at $\mathrm{pH}$ of the water below 5.5, and as the $\mathrm{pH}$ decreases, the levels of $\mathrm{Al} 3+$ in the soil increase, enhancing its toxic effect in the plant (EMBRAPA, 2006).

Aluminum is considered the greatest enemy of plants in agriculture (JANSEN et al., 2003), however, in this work, it was found that the exchangeable aluminum contents were adequately adapted to agricultural practices. Thus, the base saturation between $50-$ $70 \%$ presents a good productivity condition for the crop, excellent indication of soil fertility conditions, and is also attributed to its classification. Soils can still be classified as $\mathrm{v} \%$, thus being eutrophic (fertile) soils $=\mathrm{V} \% \geq 50 \%$; dystrophic soils (not fertile) $=$ $\mathrm{V} \%<50 \%$. As the soil under study presents a base saturation $(\mathrm{V} \%)$ natural $=\mathrm{V} \% \geq 50 \%$, this characterizes it as a fertile soil, different from another dystrophic (poor), which has a $\mathrm{V} \%<50 \%$, indicating amount of exchangeable cations, being $\mathrm{Ca} 2+, \mathrm{Mg} 2+$ and $\mathrm{K}+$ in a smaller amount retained in negative soil loads, but naturally being adsorbed by $\mathrm{H}+$ and Al+3 (RONQUIM, 2010).

Total CTC at pH 7, as shown in Table 2, was classified as high (>10 $\left.\mathrm{cmolc} / \mathrm{dm}^{3}\right)$. Soils with high cation exchange capacity have a large buffer power, this means that you will need a large amount of limestone to change the pH (RONQUIM, 2010). The management and addition of organic matter $(\mathrm{OM})$ in the system are very important, as it contributes to the cycling of nutrients and to the constitution of soil aggregates, forming a lumpy soil. Cover plants are a practice that greatly helps against soil physics damage, as well as contributes to the formation of new variable soil loads when decomposed, thus 
the OM altering the chemistry of soil colloides L (PAVAN et al., 1995). Organic material contributes from 56 to $62 \%$ of $\mathrm{CTC}$ at $\mathrm{pH} 7$, showing that it has more negative loads than any clay (RAIJ, 1969; PAVAN et al., 1985; ANBENIN; RAIJ, 1999).

Soil organic matter (MOS) was considered low, presented $1.4 \%$ or $1.4 \mathrm{dag} / \mathrm{kg}$, but it is noted that it is a material of great value for sustainable agricultural management, because its effect of directly reaching the soil can modulate the chemical, physical and biological attributes of the soil, thus becoming a great indicator of soil fertility. MOS is considered a major contributor to fertility and provides nutrients to plants, in addition to helping in soil water infiltration, water storage, soil structure and susceptibility to erosion, and other notable benefits include: cation exchange capacity, nutrient cycling, soil biota (CONCEIÇÃO et al., 2005; UNGERA et al., 1991).

The indicated is always to maintain a high MOS content (> $5 \mathrm{dag} / \mathrm{kg}$ ) to present a high CTC, pH change resistance and a higher buffer power, although it is necessary to apply larger amounts of limestone to increase the base saturation. This is due to high CTC, and the adsorption of high amounts of elements and also al3+. Because the availability of nutrients is great, vegetables can feed normally, even in the presence of Al3+ (PREZOTTI et al., 2007).

Table 2. The chemical analysis of the soil (layer of 0 to $20 \mathrm{~cm}$ ) of the Laudelino farm, located in the municipality of Teotônio Vilela, Alagoas.

\begin{tabular}{rccccccccccc}
\hline $\begin{array}{r}\text { Depth } \mathrm{pH} \\
H 20\end{array}$ & $\begin{array}{c}\mathrm{P} \\
m g / d m^{3}\end{array}$ & $\mathrm{MO}$ & $\mathrm{g} / \mathrm{kg}+$ & & $\mathrm{Ca}+$ & $\begin{array}{c}\mathrm{Mg}+ \\
\mathrm{Al}^{3}+\end{array}$ & $\mathrm{T}$ & $\mathrm{Na}+$ & $\mathrm{H}+\mathrm{Al} / \mathrm{dm}^{3}$ & $\mathrm{~V}$ \\
& & & \\
\hline $0-20 \mathrm{~cm}$ & 5,6 & 5 & 14,1 & 110 & 3,42 & 2,53 & 0.03 & 10,72 & 20 & 4,41 & 59
\end{tabular}

Legend: $\mathrm{pH}$ (active acidity) $=$ hydrogen potential, $\mathrm{P}=$ phosphorous, $\mathrm{K}+=$ potassium, $\mathrm{Ca}=$ Calcium, $\mathrm{Mg}=$ magnesium, $\mathrm{Na}+=$ Sodium, $\mathrm{Al} 3+$ (Aluminum): indicates exchangeable acidity, $\mathrm{H}+\mathrm{Al}$ (potential or total acidity): is exchangeable and non-exchangeable acidity, $\mathrm{V} \%$ (base saturation) is the proportion of cation exchange, total CTC or $\mathrm{T}=$ cation exchange capacity, $\mathrm{m} \%=\mathrm{Al} 3+$ saturation, $\mathrm{MO}=$ organic matter.

Soil analysis is of great importance in modern agriculture, being an essential practice in the soil correction and fertilization process, which begins with a good soil sampling, following with chemical analysis and the verification of the adequate amount of nutrients for an adequate application of fertilization and cathem, where this process ends with the application of the nutrients. For good efficiency in soil analysis to occur, it is necessary to have scientific knowledge so that the amounts of nutrients are 
recommended correctly, avoiding error of application of correctives and fertilizers (PECK; SOLTANPOUR, 1990).

Thus, soil analysis is the most efficient tool to quantify and evaluate fertility, correcting soil acidity and fertilization and allowing the feed to nourish banana plants adequately to have a higher productivity and thus express their genetic potential (QUAGGIO, 2001). It is very important for the establishment of a banana tree to always have fertility assessment over time, as it is essential for a more sustainable cultivation.

\section{Importance of potassium levels in soil for annual and perennial crops}

Studies by Gava (1997), Brunetto et al. (2005) and Wendling et al. (2008) reported that the availability of $\mathrm{K}$ in the soil for annual and perennial crops is the greatest limitation to productivity in soils with contents of $14 \mathrm{mg} / \mathrm{dm}^{3}$ of this nutrient, not being sufficient to meet the needs of the plants, being necessary and important its application in successive plantations to increase the amount of the nutrient in the soil.

This should be properly carried out so that there is no loss by leaching due to its transport being through mass flow. Soils containing potassium with $65 \mathrm{mg} / \mathrm{dm}^{3}$, present an average condition for plant growth and development, thus supplying their needs and making the cultivation of the crop more economical and profitable, besides providing a number of benefits to plants.

Melo et al. (2006) conducting studies in relation to the interaction between nitrogen and potassium elements during the banana growth phase, found that the soil, when well supplied with both elements, increases plant height and pseudostem circumference, presenting higher productivity and plant development, preparing it for the productive phase, which demonstrates that nitrogen and potassium have great importance in the first crop cycle, for possessing a number of benefits, not only for banana, but also for all plants.

It is important to highlight that the soil in question has medium potassium content, which makes it different from the other soils in the region. Thus, this has the potential to supply the needs of crops mainly of perennial plants such as banana trees that demands by average quantity of the element for its production, in addition, it also brings an economy in the use of fertilizer such as $\mathrm{K} 2 \mathrm{O}$. 


\section{CONCLUSION}

It is recommended to apply $1,103 \mathrm{~kg} /$ there is calcium limestone, to increase the base saturation from $59 \%$ to $70 \%$, as well as $50 \mathrm{~kg} / \mathrm{ha}$ of Nitrogen N, $343.5 \mathrm{~kg} / \mathrm{ha}$ of P2O5 and $96.7 \mathrm{~kg} / \mathrm{ha}$ of $\mathrm{K} 2 \mathrm{O}$. These quantities may be applied to the soil through sources of $837.8 \mathrm{~kg} / \mathrm{ha}$ of triple superphosphate; $161.2 \mathrm{~kg} / \mathrm{ha}$ of potassium chloride and $111 \mathrm{~kg} / \mathrm{ha}$ of urea.

It is also worth mentioning that it is also essential to add 30 to $50 \mathrm{t} / \mathrm{ha}$ organic matter (bovine manure) to the soil 30 to 60 days before planting aiming at better utilization of the material by crops. Considering that the use of organic compound as bovine manure in banana cultivation is feasible, since it grants an increase in productivity and higher yield in the crop.

Soils with medium and high potassium levels allow the implantation of more demanding crops by the nutrient, thus having lower expenditure of potassium fertilizer such as K2O. It also allowed to verify that soils with levels above $60 \mathrm{mg} / \mathrm{dm}^{3}$ of the element have the best conditions for the implantation of the most demanding crops, such as banana.

\section{REFERÊNCIAS}

BORGES A. L. et al. Nutrição e adubação. In: FERREIRA, C. F.; SILVA, S. D. O.; AMORIM, E. P.; SANTOS-SEREJO, J. A. (ed.). O agronegócio banana. Brasília: Embrapa, 2015. p. 331-398.

BRUNETTO, G. et al. SEÇÃO IV - FERTILIDADE DO SOLO E NUTRIÇÃO DE PLANTAS: Nível Crítico e Resposta das Culturas Ao Potássio Em Um Argissolo Sob Sistema Plantio Direto. N, Viçosa, MG, p. 7, 2005.

CONCEIÇÃO, P.C. et al. Qualidade do solo em sistemas de manejo avaliada pela dinâmica da matéria orgânica e atributos relacionados. Revista Brasileira de Ciência do Solo, v.29, p.777-788, 2005.

DINIZ, T. T. et al. Uso de subprodutos da bananicultura na alimentação animal. Revista Colombiana de Ciência Animal Recia, v. 6, p. 194-212, 2014.

GAVA, J.L. Efeito da adubação potássica em plantios de E. grandis conduzidos em segunda rotação em solos com diferentes teores de potássio trocável. E, Angatuba, SP, p. 6, 1997.

GUERRA, M. P. et al. Resposta da bananeira - "Branca" (Grupo AAB) a diferentes níveis de nitrogênio e potássio. In: CONGRESSO. 1986.

JANSEN, S.; SMETS, E.; HARIDASAN, M. Aluminum accumulation in flowering plants. In: BLUMEL, D. D.; RAPPAPORT, A. (Ed). Mc-Graw Hill Yearbook of Science and Technology. New York: McGraw-Hill, 2003. p. 11-13.

LSPA - Levantamento Sistemático da Produção Agrícola. IBGE, 2020. Disponível em: < https://sidra.ibge.gov.br/acervo\#/S/Q>. Acesso em: 9 de setembro de 2021. 
INGNÁCIO PROCHONOW, Luiz; ROSSI, Fabrício. Adubação e Correção do Solo. A: e recomendação de calagem e adubação, viçosa, MG, p. 389, 2009.

LÓPEZ M., A. Fertilización del cultivo de banano con diferentes doses de nitrógeno, fósforo y potássio. In: REUNIÓN DE LA ACORBAT, 10., 1991, Tabasco. Memórias... San José: CORBANA, 1994. P.65-79.

MASCARENHAS, C.J et al. projeto cadastro de fontes de abastecimento por água subterrânea estado de Alagoas: Diagnóstico do Muniá Pio de Senador Teotônio Vilela. P, Recife, PE, p. 16, 2005.

MENDES, A.M.S. Introdução A Fertilidade Do Solo. I, Barreiras-BA, p. 64, 1 jun. 2007.

MELO, B.F et al. Crescimento e produção de frutos de bananeira cultivar "Grand Naine" relacionados à adubação química. C, Fortaleza, CE, p. 4, 2006.

PECK, T.R.; SOLTANPOUR, P.N. The principles of soil testing. In: WESTERMAN, R. L. (Ed.). Soil testing and plant analysis. 3rded. Madison, Soil Science Society of America, 1990. p.1-9.

PREZOTTI, L. C. et al. Manual de recomendação de calagem e adubação para o estadodo Espírito Santo - 5o aproximação. Vitória, ES: SEEA/INCAPER/CEDAGRO, 2007. $305 p$.

QUAGGIO, J.A. Estratégias para o manejo da nutrição mineral de plantas perenes. In: Curso de atualização em nutrição mineral de plantas perenes - resumos. Campinas: Instituto Agronômico, 2001. p. 37-45.

RAIJ, B.V. et al. Recomendações de adubação e calagem para o Estado de São Paulo. Boletim Técnico, 100. 2ª ed. Campinas: Instituto Agronômico, Fundação IAC, 285 p., 1996.

RAIJ, B. van. Conceitos fundamentais na interpretação da análise do solo. In: REUNIÃO BRASILEIRA DE FERTILIDADE DO SOLO E NUTRIÇÃO DE PLANTAS, 21. 1994, Petrolina-PE. Fertilizantes: insumo básico para agricultura e combate à fome. Anais... Petrolina-PE: EMBRAPA Trópico Semiárido/SBCS, 1995. p.34-50.

RAIJ, B.V. Fertilidade do solo e adubação. Piracicaba: Ceres/Potafos, 1991. 343p.

RONQUIM, C.C. Boletim de Pesquisa e Desenvolvimento: Conceitos de fertilidade do solo e manejo adequado para as regiões tropical. B, campinas, SP, ed. 1, p. 27, novembro, 2010

SANTOS, D.R et al. Fatores que afetam a disponibilidade do fósforo e o manejo da adubação fosfatada em solos sob sistema plantio direto. F, Chapecó, SC, p. 11, 2008.

SILVA, C.A.P. et al. Avaliação do efeito imediato da adubação fosfatada e da variabilidade de plantas sobre a produção de frutos de tungue. Brasília, DF, p. 5, 2010.

VERDUM, Roberto et al. MÉTODOS E TÉCNICAS PARA O CONTROLE DA EROSÃO E CONSERVAÇÃO DO SOLO. M, Porto Alegre, RS, p. 50-54, 2016.

WENDLING, A. et al. SEÇÃO IV - Fertilidade do solo e nutrição de plantas: recomendação de adubação potássica para trigo, milho e soja sob sistema plantio direto no Paraguai. R, [s. 1.], p. 11, outubro 2008.

Recebido em: 10/10/2021

Aprovado em: 12/11/2021

Publicado em: 16/11/2021 